\title{
Transitivity Analysis on Framing in the Online News Articles
}

\author{
Agustinus Dias Suparto \\ Graduate Program \\ Faculty of Letters \\ Petra Christian University \\ agustinusdiassuparto@gmail.com
}

\begin{abstract}
News is the way to let public know about certain occurrences around the world. In Indonesia, the case of Ahok which has been sentenced for two years has been an international phenomenon. There are two factions which are opposite two each other about the case. Thus, report which can be found in the news may have different perspectives, depending on the writers'views. There are bias and framing which leads people on the writer's perspective. This paper will try to analyze two news articles on Basuki Tjahaja Purnama'scase which are taken from antaranews.com and hrw.org using Systemic Functional Linguistics (SFL). The data will be examined using transitivity analysis which can reveal the different perspectives of these two news articles by breaking down the sentences which shows the participants, process and circumstances involved. At the end of this paper, it shows how the difference in using of participants, process and circumstances creates different perspectives of the writer.
\end{abstract}

Keywords: framing, transitivity, news, Systemic Functional Linguistics

\section{Introduction}

Many people believe that news is the source of information about facts that happen in the society which is directed to the audience around the world. However, sometimes news is more interested in advancing their own objectives by using certain perspective towards the occurrences which are reported. Thus, it leads of what we call as "framing" which limits the perception of reality by limiting the perceptions of different realities and focusing on a specific piece of it (Tuchman, 1978). Thus, it results on some aspects of the reality which are perceived by the audience will be more prominent than the others. Moreover, the using of certain framing which is directed towards the audience is also influenced by the certain ideology and perspective of the writer. White (2006) has added that news reporting, especially, as ideologically inclined and with an agenda to influence its intended audience (p.1). Thus, news is also a mean to convey idea and perspective of the reader toward a certain phenomenon. It is also aimed to influence a certain audience to believe that what they have reported in news as truth. In the end, framing in news is used to influence its readers because it has certain ideology and agenda that is implied by the writer in his or her writing.

The writer often creates such opinions which can influence the reader to be affirmative of their perspectives using language in certain way. Ghannam (2011) has found that "language can be used in many different ways in order to reinforce and manipulate a message" (p.3). Hence, language in newspaper articles can be a source of creating perspective toward the readers. Mineshima (2009) has found that even when the writing is not too biased, the reader may not be aware to accept some writer's perspectives about a fact. Some of the facts are just viewed from a certain point of view which is usually directed to the target readers. Thus, language is not seen as the reflection of our reality anymore and becomes the central of creating reality (Taiwo, 2007). Therefore, whether the messages which are presented are on purpose or not by the writer, it makes a certain point of view or framing which differ one to the others

News stories which work for forming ideologies or perspectives and are directed to the readers can be analyzed using Systemic Functional Linguistics (SFL).Teo (2004) claimed that 'Transitivity', a component in Halliday's SFL, can reveal the attribution of agency to participant in 
texts and he also added that it is an analytic tool which foregrounds agency and makes salient "who does what to whom" (p.25). White (2006) added that the bias of opinion may occur because of the grammatical choices which participants are represented as agentive or as affected/acted upon. Thus, the effect of the degree of agency assigned may influence the amount of blame designated to one participant rather than another (p.3). Therefore, this study will be conducted by using Transitivity analysis to investigate the framing that is used by the writers of the texts.

\section{Framing theory}

Many people have realized that news has just reported certain occurrence in a certain perspective which later is called "framing" (Chong and Druckman, 2007, p.100). Pan and Kosicki(2001, p. 45) aptly state, "Resources are not distributed equally. Actors strategically cultivate their resources and translate them into framing power." Campaigns that have greater resources to conduct public opinion research may be better able to identify the frames that appeal most to the public. Unequal resources may also permit one side to advertise its themes more frequently (and to a wider audience) and to enlist representatives and endorsers that can more credibly deliver its messages to the public (Chong \& Wolinsky-Nahmias, 2003). They added that there are actually two kinds of frame which are media frame and individual frame. A frame in communication or a media frame refers to the words, images, phrases, and presentation styles that aspeaker (e.g., a politician, a media outlet) uses when relaying information aboutan issue or event to an audience (Gamson \& Modigliani, 1987, 1989). Related to media, this frame is affected by the point of view of the writer on how his or her writing wants to be read by the readers. The side that is taken by the writer is aimed to influence the audiences to see the phenomena in the perspective of the writer. News, therefore, are textual and visual structures built around a central axis of thought, from a certain perspective, and by information professionals (but not only by them), who will provide an interpretive framework for the audiences exposed to the news messages.

On the other hand, a frame in thought or an individual frame refers to an individual's cognitiveunderstanding of a given situation (e.g., Goffman, 1974). Unlike frames incommunication, which reflect a speaker's emphasis, frames in thought refer to whatan audience member believes to be the most salient aspect of an issue.Politics is typically competitive, fought between parties or ideological factions, and issues that are debated are framed in opposing terms. Individuals receivemultiple frames with varying frequencies.Theriault (2004) found that individuals favored the frame that was consistent withtheir values.Sniderman and Theriault concludedthat framing might be less influential in politics than experimental studieshave suggested because competing frames may cancel each other and fail to movepublic opinion (Brewer \& Gross, 2005). Therefore, the effectiveness of any framing strategy will depend on its design andimplementation within a particular competitive environment.

\section{Systemic Functional Linguistics}

Halliday (1990) proposed theory of linguistics that claims language, or any other semiotic systems, can be seen as a system of choices which is called Systemic Functional Linguistics (SFL). He claimed that SFL is particularly suitable for the type ofinvestigation that

“... enables us to analyse any passage and relate it to its context in the discourse, and also tothe general background of the text: who it is written for, what is its angle onthe subjectmatter and so on(p. 34)".

In other words, Halliday's SFL emphasizes how language is used to express meaning. Some linguists agreed that it is a systematic way to analyze how language works or functions in communication. Bloor and Bloor (1995) also agreed that SFL is semantic means that it concerns with the meaning and also functional which means it concerns with how the language is used (p.2). Therefore, White (2000) concluded that SFL is a popular tool to investigate how linguistic items and grammatical patterns are used to express different semantic values.

\section{The Three Metafunctions}


In SFL, Halliday (1985) also proposed three interrelated metafunctions, which are the Ideational or Experiential, the Interpersonal and the Textual to classify the various options available and choices by the speakers. He later claimed that:

"Language has developed in response to three kinds of social-functional needs. The first is to be able to construe experience in terms of what is going on around us and inside us. The second is to interact with the social world by negotiating social roles and attitudes. The third and final need is to be able to create messages with which we can package our meanings in terms of what is new or given." (Halliday, 1994, p.11)

From his statement, the Ideational or Experiential relates to the way languages is used to express the perceptions of the world and explains how the language is used to describe 'doings' and 'happenings'. The Interpersonal metafunction refers to language as medium for interaction, expressing attitudes and obligation. Then, The Textual metafunction refers to 'the enabling function, thespeaker's text-forming potential expressing the relation of language to its environment andweaving together the experiential and interpersonal meanings' (Plemenitas, 2004, p. 26).However, this paper only examines the texts from ideational metafunction perspectives which only focused on the process, actors and circumstances of the texts.

\section{Transitivity}

Part of ideational or experiential function, which concerns with the transmission of ideas, is transitivity (Cunanan, 2011, p. 72). The system of transitivity specifies the different types ofprocesses and consists of the process itself, participants in the process (e.g. actor, goal, beneficiary) and circumstances attendant on it (Plemenitas, 2004, p. 27). The following clause, Figure 1 taken from text A, shows an example how the Participants, Process and Circumstances work.

Figure 1

\begin{tabular}{|l|l|l|l|}
\hline Discriminatory laws & Puts & Religious minorities & At risk \\
\hline $\begin{array}{l}\text { Participant } \\
\text { (Actor) }\end{array}$ & $\begin{array}{l}\text { Process } \\
\text { (Material) }\end{array}$ & $\begin{array}{l}\text { Participant } \\
\text { (Goal) }\end{array}$ & $\begin{array}{l}\text { Circumstances } \\
\text { (Contingency) }\end{array}$ \\
\hline
\end{tabular}

Halliday (1976) claimed that transitivity represents process or experiences like actions, events, processes of consciousness, and relations that covers "all phenomena and anything that can be expressed by a verb: event, whether physical or not, state or relations" (p. 159). Hence, transitivity basically presents how the world is perceived in three dimensions: the material world, the world of consciousness and the world of relations (Cunanan, 2011, p. 73).

There is more detailed process type system which relates the process with its participants: Material process has many kinds of participants such as Actor, optional participants like Goal, Range, Beneficiary,which can be Recipient or Client, Attribute. Mental process has Senser andPhenomenon. Verbal process has participants Sayer, optional participants Receiver, Verbiage and Target. Behavioral process has participant Behaver, or optional Behaviorwhich can be Phenomenon or Verbiage. Existential process has participant Existent. Relational process is further divided into Identifyingwith participants Token and Value, and Attributivewith participants Carrier and Attribute, optional Beneficiary. (Plemenitas, 2004, p. 30)

Circumstancesare the indispensable part of each process type. These circumstances are comprehended by prepositional and adverbial phrases. These circumstances can be classified as: Extent and Location, Manner such as means, quality and comparison, Cause such as reason, purpose and behalf, Contingency such as condition, concession or default, Accompaniment such as comitative or additive, Role such as guise and product, Matter and Angle

\section{Data and Method}

The data which were discussed were taken are two online newspaper articles about Ahok's trial regarding the blasphemy that has been the controversy in Indonesia titled ("Ahok sentenced for two years ...") taken from Indonesian online newspaper, antaranews.co.id and ("Indonesia sends Jakarta Governor in prison ...") taken from hrw.org which is not online Indonesian newspaper. These two articles are chosen to know the perspectives and framing that is used from the local and abroad journalist about the case of Ahok. The data will be analyzed using transitivity 
analysis in which the processes, participants and circumstances are examined. By understanding the element of transitivity analysis, the framing of both articles will be determined.

\section{Findings and Discussion}

The transitivity which was conducted was seeking the three elements of Transitivity which are the process, participants and circumstances in the texts. The analysis focused on the dominant types of each element to understand the style of the writer to reveal the purpose and their point of view which determines the framing that was implied in the text. Therefore, the first step that was done is to determine the most dominant Process, Participants and Circumstances that are used in the texts.

\section{The Most Dominant Process Type}

In order to determine which processes were dominant of the texts, which the texts chosen were two online newspapers from different country which have been mentioned before, the processes were placed into several categories mentioned below. The dominant process type would determine the dominant participants that would later be discussed

\section{Process Type}

\begin{tabular}{|c|c|c|c|c|}
\hline Process & \multicolumn{2}{|c|}{ Text 1 } & \multicolumn{2}{c|}{ Text 2 } \\
\hline Material & 6 & $33.3 \%$ & 8 & $53.3 \%$ \\
\hline Mental & 3 & $16.7 \%$ & 3 & $20.0 \%$ \\
\hline Verbal & 5 & $27.7 \%$ & 1 & $6.7 \%$ \\
\hline Relational Attributive & 1 & $5.6 \%$ & 1 & $6.7 \%$ \\
\hline Relational Identifying & 3 & $16.7 \%$ & 2 & $13.3 \%$ \\
\hline
\end{tabular}

The table shows that there are only five process types that can be found in both texts and the differences in using those processes in both texts are not significant. Thus, it is clearly stated that material process which describes physical activities dominates in those two texts. Material processes that are used mostly in the texts shows that both writers want to describe what actually happened in neutral way. By using material process, it is also implied that both articles want to show the fact to the audience. The example how those texts show the reality using material process can be seen in the figure below.

Material Process in Text 1

\begin{tabular}{|l|l|l|}
\hline Participants (Actor) & Process (Material) & Circumstances (Location) \\
\hline Ahoks blasphemy trial & began & on December 13, 2016 \\
\hline
\end{tabular}

Material Process in Text 2

\begin{tabular}{|l|l|l|l|}
\hline Participants (Actor) & $\begin{array}{l}\text { Process } \\
\text { (Material) }\end{array}$ & Participants (Goal) & $\begin{array}{l}\text { Circumstamces } \\
\text { (Means) }\end{array}$ \\
\hline $\begin{array}{l}\text { The law, article 156a } \\
\text { of the Indonesian } \\
\text { criminal code }\end{array}$ & punishes & $\begin{array}{l}\text { deviations from the central tenets } \\
\text { of the six officially recognized } \\
\text { religions }\end{array}$ & $\begin{array}{l}\text { with up to five years in } \\
\text { prison }\end{array}$ \\
\hline
\end{tabular}

Both texts use real data such as when the trial began in text 1 and the law that is used to punish Ahok in text 2. There are also material processes which display how the trial was and its implications toward the two factions of people which are supporting or against Ahok in this case. Not only the use of material process, the use of relational attributive and identifying also add more explanation about the case, especially for the readers who do not know much about the case. However, the use of mental processes in both text create the sense of opinion from the writer as the writers want to describe the feeling of the people involved and what on the mind of those people. Moreover, text 1 wants to present what people think about the case by adding the quotations of the interview that was conducted by using verbal processes whereas in text 2 , there is only one verbal process which is about what Ahok says related to his case and the trial. The using of verbal process 
creates the opinion toward what actually happens in Ahok's case, thus, it creates certain point of view of the writer regarding on whom is quoted in the article. Later, the participants who are involved the most in the texts will be discussed in the next session.

\section{The Most Participant Used in the Texts}

Plemenitas (2004) stated that 'agents' or participants are interpreted as the function which typically has the power to determine whether or not the process will occur or in other words, it is the controller of the process (p.35). Halliday (1994) earlier has mentioned that Transitivity also features of causation which the process comes to exist. Therefore, the evaluation of kind of participants cannot be separated from the process type that is involved. He also added the terms used for the participants that are influenced by its process such as actor and goal in material process. Moreover, the participants that are involved in the process can also affected by whether the clause is active of passive as Thompson (2004) distinguished between those Material processes that represent action related only to the actor and those that "also affect or are 'being done' to another participant", in this case categorized as the goal (p.90). Thus, the participants that are involved as the result of the process used in the texts are displayed in the table below.

Participants

\begin{tabular}{|c|c|c|c|c|}
\hline Participants & \multicolumn{2}{|c|}{ Text 1 } & \multicolumn{2}{c|}{ Text 2 } \\
\hline Actor & 4 & $12.5 \%$ & 4 & $16.7 \%$ \\
\hline Goal & 4 & $12.5 \%$ & 7 & $29.1 \%$ \\
\hline Senser & 3 & $9.4 \%$ & 2 & $8.3 \%$ \\
\hline Phenomenon & 3 & $9.4 \%$ & 3 & $12.5 \%$ \\
\hline Sayer & 5 & $15.6 \%$ & 1 & $4.2 \%$ \\
\hline Verbiage & 5 & $15.6 \%$ & 1 & $4.2 \%$ \\
\hline Career & 1 & $3.1 \%$ & 1 & $4.2 \%$ \\
\hline Attribute & 1 & $3.1 \%$ & 1 & $4.2 \%$ \\
\hline Identified & 2 & $6.3 \%$ & 2 & $8.3 \%$ \\
\hline Identifier & 3 & $9.4 \%$ & 2 & $8.3 \%$ \\
\hline Scope & 1 & $3.1 \%$ & 0 & $0 \%$ \\
\hline
\end{tabular}

The table shows that actor is the most dominant participant in text 1 whereas goal is the most dominant in text 2 as the Material process dominates both texts. As it has been explained before, the actions which are involved in the texts mostly are caused by the function of the texts which are giving the actual descriptions about the match. Plemenitas (2004) assumed that actors are 'agents as the real instigators or controllers of the process' (p.35). In other words, actors are participants which are active in determining the process, which is the Material process and the using of actors supports the texts to give information about "who is actively involved" in the case. As there are two groups of people who support Ahok's blasphemy case and oppose his imprisonment, the writer also tries to convey his perspective using the participants involved in the text. It can be clearly seen in the actors and goals that are used in the material processes in the texts like in the table below.

\begin{tabular}{|l|l|c|c|c|}
\hline \multicolumn{2}{|l|}{} & Pro-Ahok & Neutral & Anti-Ahok \\
\hline \multirow{2}{*}{$\begin{array}{l}\text { Text } \\
1\end{array}$} & Actor & 0 & 3 & 1 \\
\cline { 2 - 5 } & Goal & 3 & 1 & 0 \\
\hline \multirow{2}{*}{$\begin{array}{l}\text { Text } \\
2\end{array}$} & Actor & 0 & 4 & 0 \\
\cline { 2 - 5 } & Goal & 2 & 5 & 0 \\
\hline
\end{tabular}

This table shows the participants especially the actors and goals with their affiliation with the factions which support and oppose Ahok's case and neutral side such as the court and the government. From the table, it can be found that both texts try not to take side by using neutral side as participants to talk about the case. However, Basuki Tjahaja Purnama or Ahok as the defendant 
in the trial is mentioned by both texts as the goal that of the action that is done by the court and Indonesian blasphemy law which are dominating the actor used in the two texts. This implies that both texts try to present the reality which is about the court where the judges have the authority in the court to sentence Ahok as the defender of his blasphemy case. Therefore, as Kosicki (2001) claimed that resources in the media are not distributed equally, both texts to be focused on the process in the court as the judges have more power to do over Ahok as the defendant and as the goal of the implementation of blasphemy law. Thus, the framing that is built in these articles is on how Ahok is punished by the judges as the consequences of the blasphemy law in Indonesia.

Moreover, mental process and verbal process also play part in framing that is used in both texts. This can be seen in the text 1 where verbal process also used quite often to give the opinions about the trial. In text 1 , there are two verbal processes that are done by Ahok and his lawyers about their opinion about the sentence and one verbal process when he had speech in Kepulauan Seribu. The two other verbal processes are done by Bachtiar Nasir as the person who opposes Ahok and wants Ahok to be imprisoned because of the blasphemy. Thus, text 1 wants to offer different perspectives over the sentenced that is given to Ahok as the defendant of blasphemy case. On one hand, Ahok's side feels object with the punishment whereas his opposition is satisfied with his imprisonment. Text 1 also tries to be neutral in using of the words to name the participants such as Pro-Ahok and Anti-Ahok to describe the supporters of each faction. Therefore, in text 1, the framing that is used to lead the readers using the description of the trial process done by the judges to punish Ahok and the reactions from Ahok's side and Bachtiar Nasir as the supporter of blasphemy law toward ahok.

That is different with text 2 where it focuses more on how the blasphemy law is used to punish Basuki Tjahaja Purnama. The using of the words to describe the participants such as Militant Islamist groups and Ahok, a Christian create sense that the writer has his or her own opinion towards the case that the blasphemy law is used to oppress the minority because of intolerant people in Indonesia. However, the writer is not clearly stated that the main source of the case is the using of blasphemy law by those intolerant people by not mentioning the actors in which Ahok is positioned as the goal as the result of the law. It implies on the number of actors which is outnumbered by the goal as Ahok is mentioned two times as the goal. In general, the article is blaming the Indonesian authorities because of the use of blasphemy law in Indonesia which puts the minorities in danger and urges the government, especially Joko Widodo as the president of Indonesia to banish the blasphemy law. Therefore, as the article is made not by Indonesian and published for the readers worldwide, it focuses more on criticizing the use of blasphemy law in Indonesia without describing the situation during the trial, etc. Finally there are two kinds of framing used in these two articles which are focusing more on the description during Ahok's trial and its reactions from the both factions and the other one is focusing on the using of blasphemy law in Indonesia that harms Indonesian harmony and puts the minorities in danger.

\section{Circumstances in the Texts}

The other transitivity component is circumstances which are propositional and adverbial phrases. However, in Transitivity analysis, circumstances just show the clue about participants and the processes in terms of time, place, condition, reason, comparison, etc. Therefore, circumstances can only help the Transitivity analysis in terms of the purpose of the text or the kind of text. As we can see, there are several kinds of circumstances used in the text to help the writer explain the situation like in the table below.

Circumstances

\begin{tabular}{|c|c|c|c|c|}
\hline Circumstances & \multicolumn{2}{|c|}{ Text 1} & \multicolumn{2}{c|}{ Text 2 } \\
\hline Location & 8 & $50 \%$ & 2 & $12.5 \%$ \\
\hline Matter & 4 & $25 \%$ & 7 & $43.75 \%$ \\
\hline Cause & 1 & $6.25 \%$ & 3 & $18.75 \%$ \\
\hline Extent & 1 & $6.25 \%$ & 0 & $0 \%$ \\
\hline Contingency & 1 & $6.25 \%$ & 0 & $0 \%$ \\
\hline Means & 1 & $6.25 \%$ & 4 & $25 \%$ \\
\hline
\end{tabular}


From the table, it shows that Location is dominating in text 1 whereas Matter is used the most in text 2. Location is a circumstance which provides information about when and where the process happens or in the other word; location shows the time and the place of the occurrences during the trial. Thus, the information provided from Location circumstances, it gives us clear descriptions about what were going on in the court. Thus, by using more Locations, text 1 wants to describe more on the trial's situation. Matter is used to give explanation about something which is used more in text 2 as it wants to give explanation about what happens in Ahok's case and how that case is related to the using of blasphemy law that is being criticized in the text. Moreover, the using of Means in text 2 also provides more information on how the blasphemy law is used to imprison Ahok and how it is used to oppress the minorities in Indonesia. Thus, circumstances used also influence the way of writing which results on the framing that is used in the articles.

\section{Conclusion}

From the discussion, it shows that actors who are involved in the texts can assist the writer to take aside and influence the readers to see the writer's perspective through the framing that is used. Therefore, news is seen as the structure that is built based on the thought from certain perspective done by the writers to provide the limited information for the readers. Thus, as the writers of the two articles that are compared in the discussion, it shows how participants, process and circumstances that are used in the text create a certain perspective that the writers want to focus on. As the text 1 wants to focus more on the situation during the trial in Ahok's case and the reactions of the factions of people who support and oppose Ahok, it uses more Material process with more Location circumstances to explain the situation about the time and place clearly. The using of equal actors or the active participant and the goal or the passive participant in Material process also creates the sense that text 1 wants to show neutrality by giving equal perspective from both sides. Different with text 1 , text 2 focuses more on how the government uses blasphemy law as the mean to oppress the minority in which Ahok is imprisoned because of quoting a verse in $\mathrm{Al}$ Quran. Although it is not clearly stating that Ahok's case is caused by the intolerant Muslims that put pressure to the authority, it is implied that the writer wants to object the using of the law to criminalize Ahok because he is a minority in Indonesia. By using Matter circumstances to explain how Ahok's case develops, the writer wants to direct International readers to see how blasphemy law in Indonesia is used to oppress the minority.

Finally, herein the importance of studying Functional Linguistics especially transitivity system which highlights the linguistic choices made by three writers to show how those choices assign agency. By using transitivity analysis which examines the processes, participants and circumstances of the text, the positions of the reader to accept positive or negative point of view of the participants of the texts are likely able to be figured out. Thus, framing that is used to direct the reader about an occurrence can also be analyzed using Transitivity analysis.

\section{References}

Ahok Sentenced to Two Years Imprisonment for Insulting Islam. Retrieved on June $1^{\text {st }}, 2017$ from www.antaranews.com/en/news/110848/ahok-sentenced-to-two-years-imprisonmentfor-insulting-islam

Ghannam, D. (2011). Newspaper Ideology: A Critical Discourse Analysis of An Event Published in Six Lebanese Newspapers. Johannesburg: University of the Witwatersrand

Halliday, M.A.K. (1985). Introduction to functional grammar. London: Arnold.

Halliday, M.A.K. (1994). An Introduction to Functional Grammar. London: Edward Arnold.

Kine, P. (2017). Indonesia Sends Jakarta Governor in Prison for Blasphemy www.hrw.org/news/2017/05/09/indonesia-sends-jakarta-governor-prison-blasphemy

Mineshima, M. (2009). Discourse Analysis of News Texts by the Application of Systemic Functional Grammar. Niigata Institute of Technology. Pp. 101-123

Plemenitas, K. (2004). Some Aspects of the Systemic Functional Model in Text Analysis. Ljubljana: Birografika Bori.

Thompson, G. (2004). Introducing Functional Grammar ( $2^{\text {nd }}$ ed.). London. Arnold. 
White, P. R. R. (2006). Evaluative Semantic and Ideological Positioning in Journalistic DiscourseA New Framework for Analysis. In Larsen, I (ed.). Mediating Ideology in Text and Image: Ten Critical Studies. John Benjamins, Amsterdam. Pp. 37-69 